Jpn. J. Med. Mycol.

Vol. 34, 253-263, 1993

ISSN $0916-4804$

総 説

Compromized host に発症する深在性真菌症

に関する病理学的研究

\author{
渋 谷和 俊 若山恵 直 江 史 郎 \\ 東邦大学大橋病院病理学研究室
}

\begin{abstract}
要旨
日和見感染症として発症する代表的な深在性真菌症の中から, カンジダ症, アスペルギルス症および クリプトコックス症を選び, いくつかの実験を加え, 病理組織学的に検討した.

この結果, 白血球減少状態では, 著明な菌の増殖に対し壊死や炎症細胞浸潤が極めて微弱であること や菌の組織内への侵入や增殖の防御にも末梢血中の白血球が深く関与していることなどが，より明瞭と なった. また, 化学療法の進歩が, 白血病患者におけるカンジダ症の抑制に奏奻し始めている可能性が, 本学の剖検例の推移から指摘された。一方，原発性および続発性肺クリプトコックス症を比較すると， 後者では暴胞病変を形成することが多く，実験的には CD4+細胞を抑制することで再現することが可 能であった。

ヒトの Immunocompromized condition は, 多数の防御能隇弱因子の複合状態であり, Immunocompromized hostにおける易感染状態の程度や質と病理組織学的変化との相関を明瞭に規定するこ とは，現時点では困難な事象と考えられる。しかし，病理学的に真菌感染巣は，生体の動的な防御反応 である炎症の一断面として捉えられ，特にImmunocompromized hostに成立する病変では，港出反 応が著しく乏しい点を特徵の一つと考えたい.

Key words：易感染性宿主（Immunocompromized host），カンジダ症 (Candidiasis)，白血 病（Leukemia），アスペルギルス症（Aspergillosis），肺クリプトコックス症 (Pulmonary cryptococcosis)
\end{abstract}

我が国における深在性真菌症の大半は, Candida, Aspergillus, Cryptococcus およびMucorによる 感染症であり, その多くは, 日和見感染症として 発症している. また, Compromized host の增加 に伴った症例数の漸増傾向と診断法確立の重要性 は, 医真菌学領域の熱心な研究者たちによって, 以前から指摘されてきた点である。

我が国では, 今世紀初頭から散発的な症例報告 があり ${ }^{1)}$, この時点ですでに深在性真菌症の発症 に関与する現在の Compromized hostの概念が

別刷請求先 : 渋谷 和俊

干153 目黑区大橋 2-17-6

東邦大学大橋病院病理学研究室
導入されていたものも含まれていた2). その後, 奥平ら1)により系統的な深在性真菌症に関する病 理学的研究が行われ, 病変の病理学的特徽や, 診 断に重要な病巣内における菌形態の詳細が明らか にされて来た。

さて, カンジダ症やアスペルギルス症などの代 表的な深在性真菌症の共通する所見として, 組織 の壊死と, これを中心とした様々な程度の炎症細 胞浸潤が上げられる。この炎症細胞浸潤の程度や 種類は, 宿主の基礎疾患とある程度相関をもつと 推定されるものの，その詳細は，未だに不明とい わざるを得ない.一方, 基礎疾患を持たない患者 にも発症する点から原発性深在性真菌症としても 
捉えることのできるクリプトコックス症では, 多 くの場合，健常者では肉芽腫を，また日和見感染 として発症した場合には，組織の壊死がほとんど みられない襄胞病変を形成する ${ }^{3)}$ 。このように， Compromized host に発症した深在性真菌症では, 宿主の状態や菌の種類，あるいはその毒力に応じ て, 極めて多彩な病変が感染臓器に観察される。 ここでは，発症頻度の高いカンジタ症とアスペル ギルス症に加え，宿主の感染防御能の差に基づく 感染病巣の形態的比較が可能であるクリプトコッ クス症を材料として, 病理学的検討を行なった結 果を報告したい.

\section{1.カンジダ症}

1 ) 白血病患者におけるカンジダ症の推移とそ の病理

ヒトの Compromized conditionは, 減弱した 多数の感染防御に関与する因子の複合状態であり， その質や防御能低下の程度を客観的に掌握するこ とは，臨床的にはもとより病理学的にも困難な問 題と考えられる.しかし，この中でも代表的な深 在性真菌症の基礎疾患である白血病では，末梢血 白血球数が, 宿主抵抗性の減弱の指標として，あ る程度の相関を有することが知られている4)。そ こで, 白血病剖検例に認められた深在性真菌症の 経年的推移や敗血症発症時に比較的高頻度に病変 が成立する腎におけるカンジダ感染巣の組織像に
関する検討を行なった.

Fig. 1 は, 1981 年から 1990 年までの本学大森 病院における白血病剖検例数とこれに合併した深 在性真菌症の経年的推移を実数ならびに合併率で 示したものである（Fig. 1). 剖検数は，4 例から 17 例の間を推移しているが, 1985 年以後, 真菌症 の合併頻度の低下傾向が伺える．また, 1987 年及 び 1990 年では, 白血病剖検例に合併した深在性 真菌症は 1 例もなく，この両年がそれぞれ Miconazole と Fluconazole の静注剤の上梓翌年に相当す ること，特に，血液疾患を主に取り扱う本学第 1 内科では, 1989 年から白血病患者に対する化学療 法開始時に, 大半の症例で Fluconazole の予防投 与が行なわれていることを考慮すると，この数年 は, 抗真菌剂の普及が, 白血病患者における真菌 症発症の抑制に効を奏し始めた時期として捉える ことができよう。一方，この白血病剖検例に合併 した深在性真菌症の病原菌の内訳は（Fig. 2), Candida spp. が最も多く, 次いで Aspergillus spp. の順で，他施設の報告と一致している．従っ て白血病に合併する深在性真菌症の減少には，他 の真菌症に比して圧倒的に高頻度に発症するカン ジダ症の減少が寄与する点が大きいと思われる， しかし，これらの成績は本学のみのものであり， 検索症例数も少なく，これを実証するには，複数 の施設による大規模な統計調查と詳細な症例解析 が必要であることはいうまでもない.

\section{Number of Leukemic Patients and Fungal Infections}

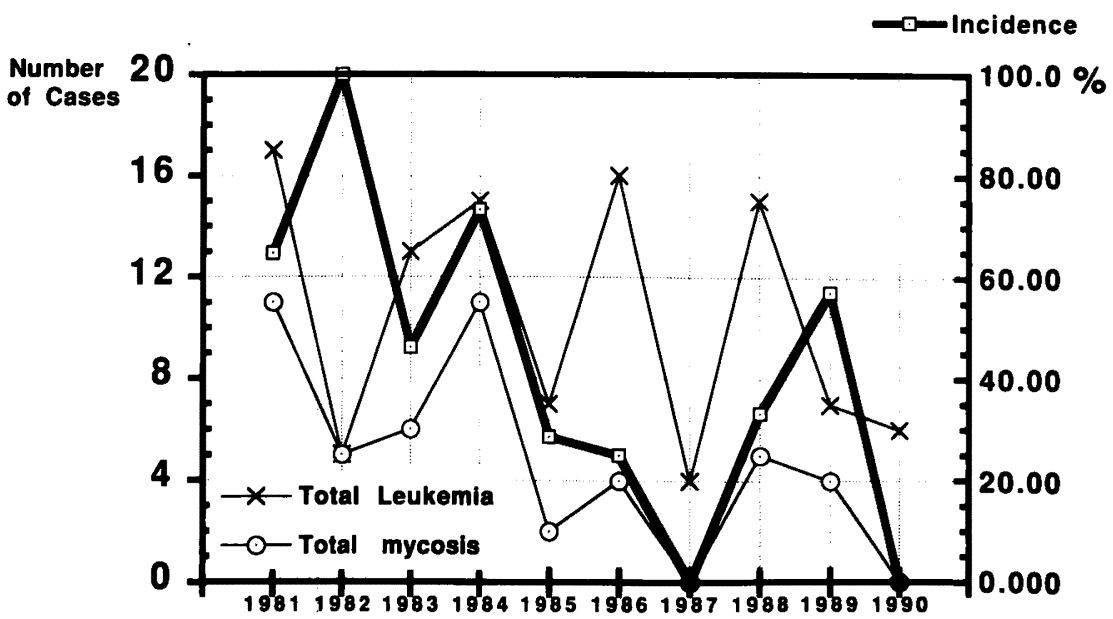

Fig. 1. Number of leukemic patients and incidence of fungal infections. 


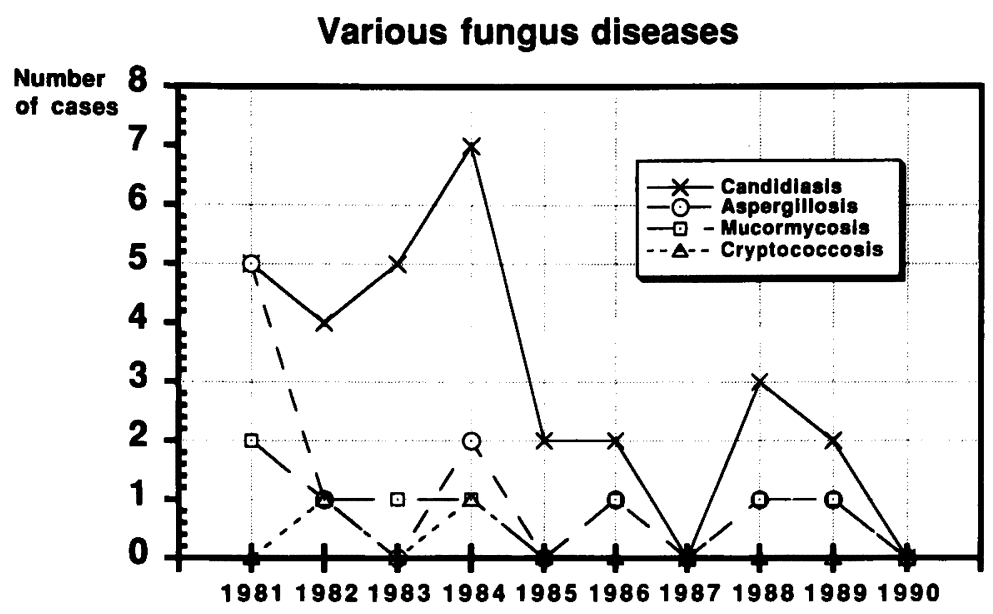

Fig. 2. Annual incidence of various fungal diseases

つぎに, 白血病患者に発症したカンジダ症の組 織像について検討し, Compromized host と深在 性真菌症の発症, あるいはその病変の拡大につい て, 若干の考察を加えてみたい.

検索材料として, 全身性カンジタ症で比較的合 併頻度が高く, 実質臓器であるために病変の形態 的比較が容易であることから，腎を選択した．対 象となった症例は，腎にCandidaの増殖を認めた 白血病剖検例 6 例である. 死亡直前の末梢血白血 球数は, 3 例が $1,000 / \mathrm{cmm}$ 以下であり, 残り 3 例 が約 3,000/cmm から 10,000/cmm（Fig. 3）で, この中には，経過中に顆粒球輸血を施された例が 1 例含まれている. 白血球数 $1,000 / \mathrm{cmm}$ 以下の 3 症例では,ほほ同様の組織学的所見を呈する腎病 変が認められた.すなわち, それらは菌系性発育 を主体とした菌の均等な遠心性増殖であり, 壊死 巣はこの菌の増殖部にほほ一致し, 炎症細胞浸潤 は，ほとんど認められないものである (Fig. 4). これに対し，末梢血白血球の維持されていた症例 群では, 菌の増殖部周囲に壊死巣と様々な程度の 多形核白血球の浸潤が認められた（Fig. 5).また， 顆粒球輸血を施された症例では, 末梢血白血球数 が 1,000/cmm で経過し, 死亡の約 2 週間前から 感染症が疑われたためにこの処置が施されたにも かかわらず, 病変部には多形核白血球の浸潤が著 明であった. 以上の点から, 末梢血白血球数と病 変部における多形核白血球の浸潤には, ある程度 の相関があると推定できよう。 また, 汎白血球減

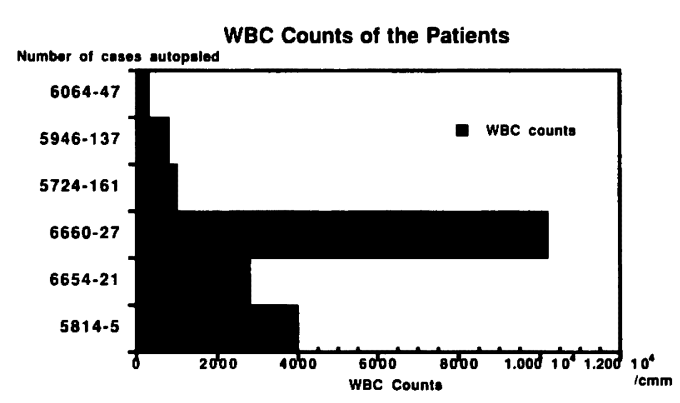

Fig. 3. White blood cell counts of examined patients.

少状態では, 宿主は, 組織内での速やかな菌の増 殖を容認し,このときに, 壊死巣が菌の周囲に拡 大しないことから, 病変部に認められる壊死には 生体内における Candida の増殖に基づく活性物質 の放出のみならず, 活性酸素をはじめとする顆粒 球由来の組織障害物質の関与が示唆された。ささら に,アロ顆粒球の移入によっても末梢血白血球の 維持されていた患者と同様の組織反応が惹起され ることから, Compromized hostにおける感染で もCandidaの組織への定着と増殖によって, 感染 防御を担当する細胞に対する走化性因子をはじめ とする何らかのシグナルが発現していると推定さ れた.さらに, 病変部におけるシグナルの発現に は，顆粒球自体の関与は少ないものと考えられた。

2 ）治療による組織像の变化

前述のように, 全身投与可能な抗真菌剂が普及 した結果, 臨床的に深在性真菌症の確定診断が下 

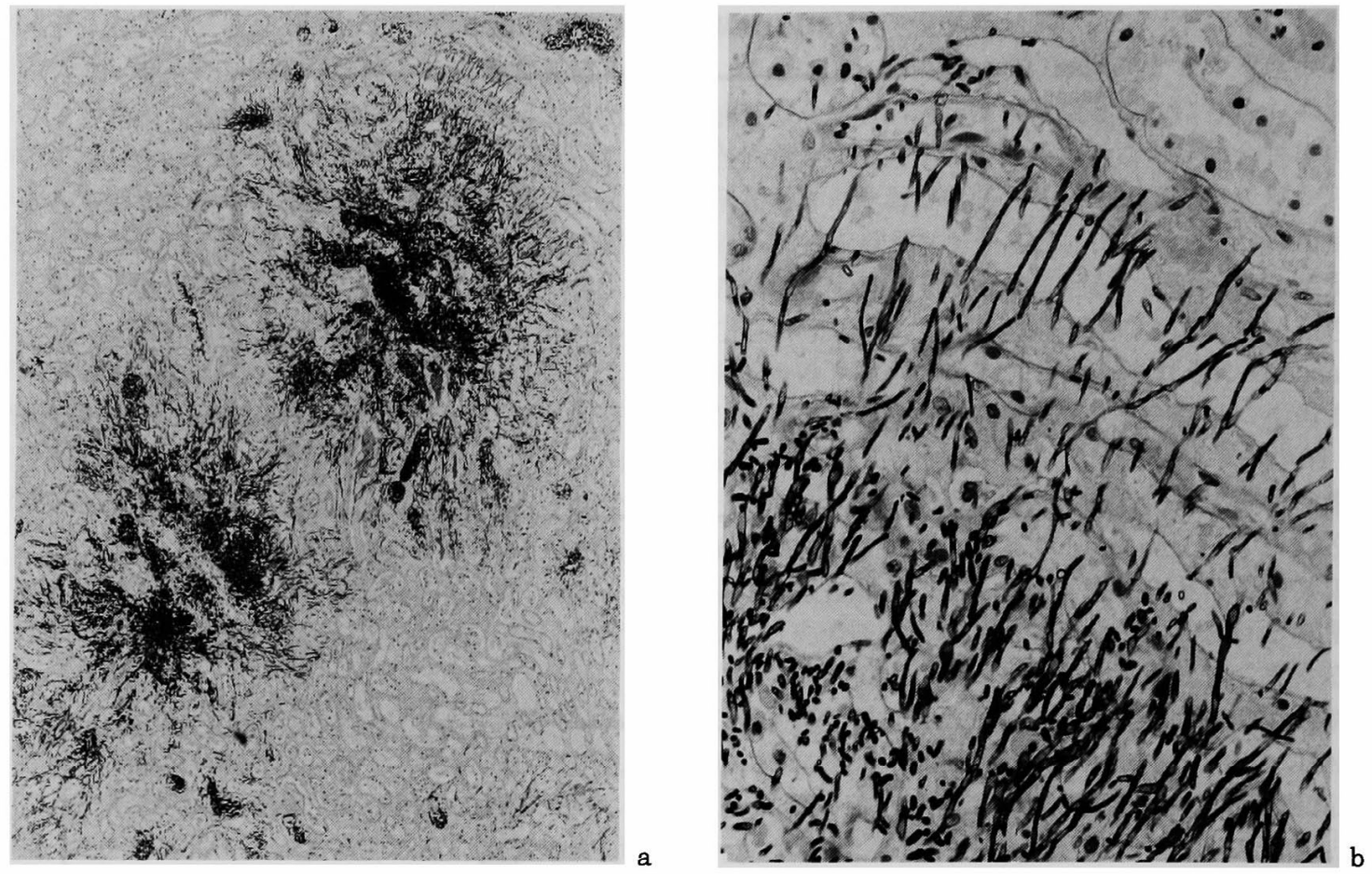

Fig. 4. Foci of candidial infection in the kidney, apparently showing fewer inflammatory cell infiltrates. (PAS reaction, a : $\times 40, \quad b: \times 400$ )
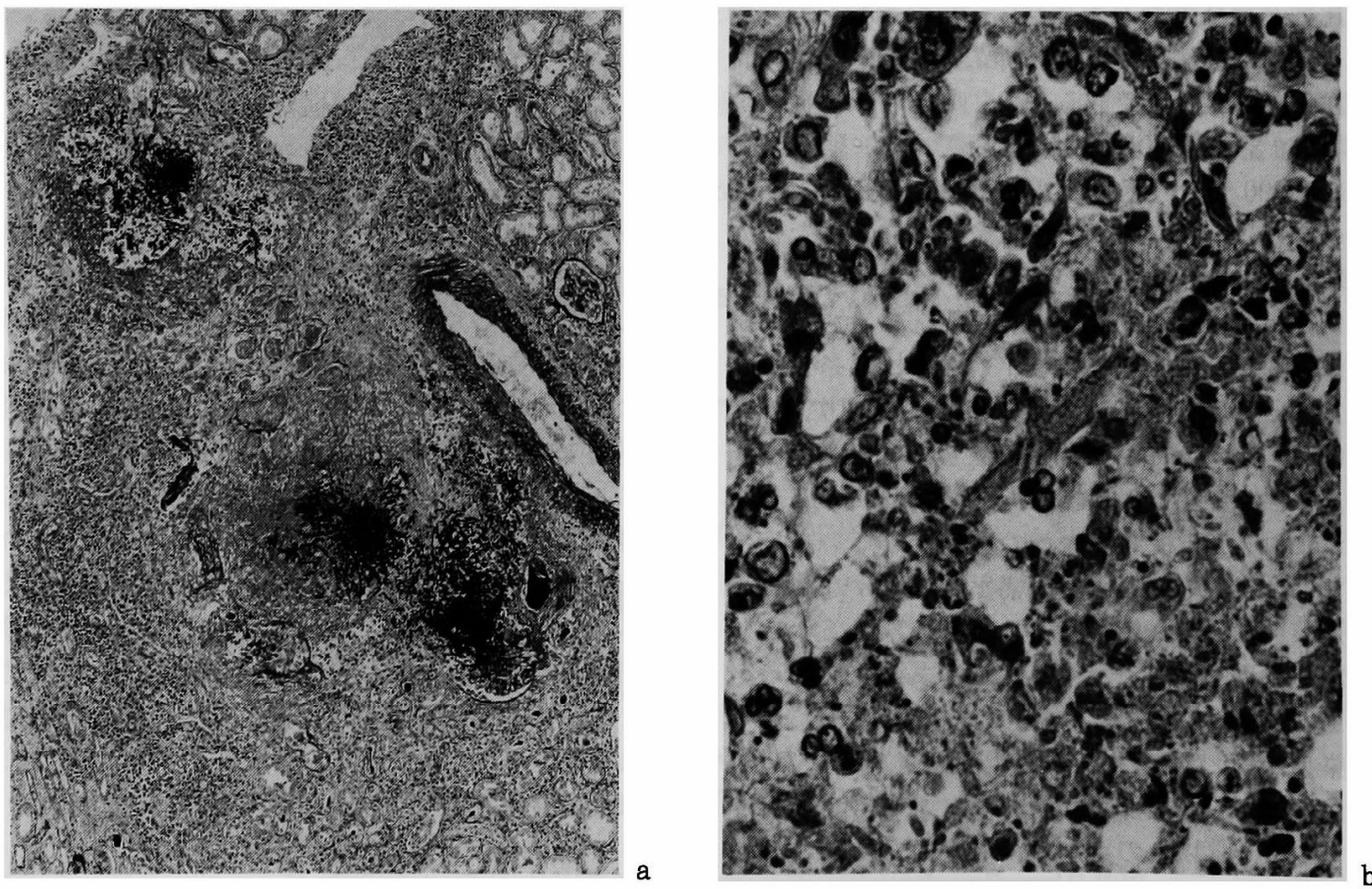

Fig. 5. Foci of candidial infection in the kidney, showing necrosis and polymorphonuclear cell infiltrates. (PAS reaction, a $: \times 40, b: \times 400$ ) 

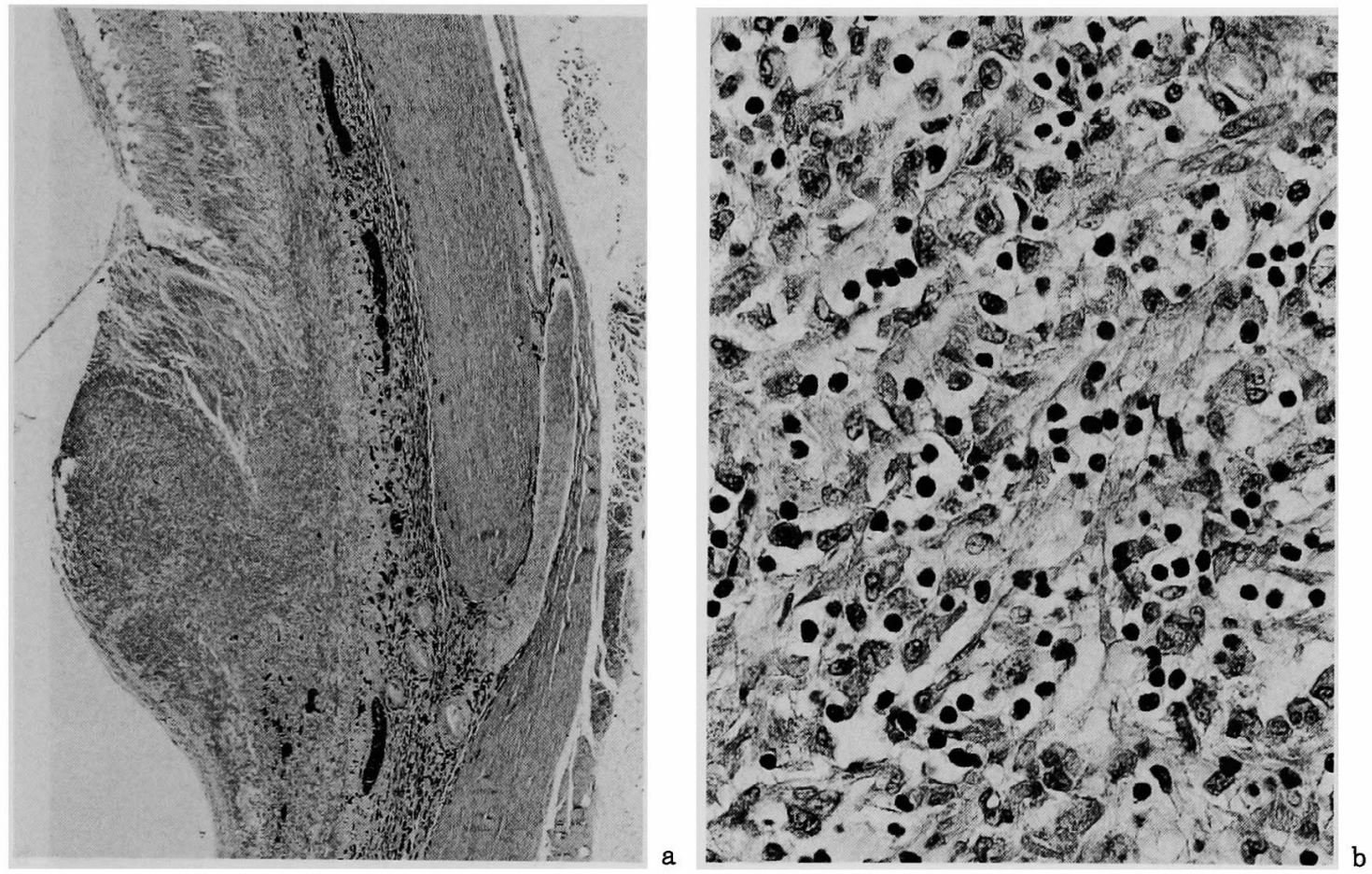

Fig. 6. Histology of the candidial endophthalmitis appearing in a treated case. (PAS reaction, $\mathrm{a}: \times 10, \mathrm{~b}: \times 320)$
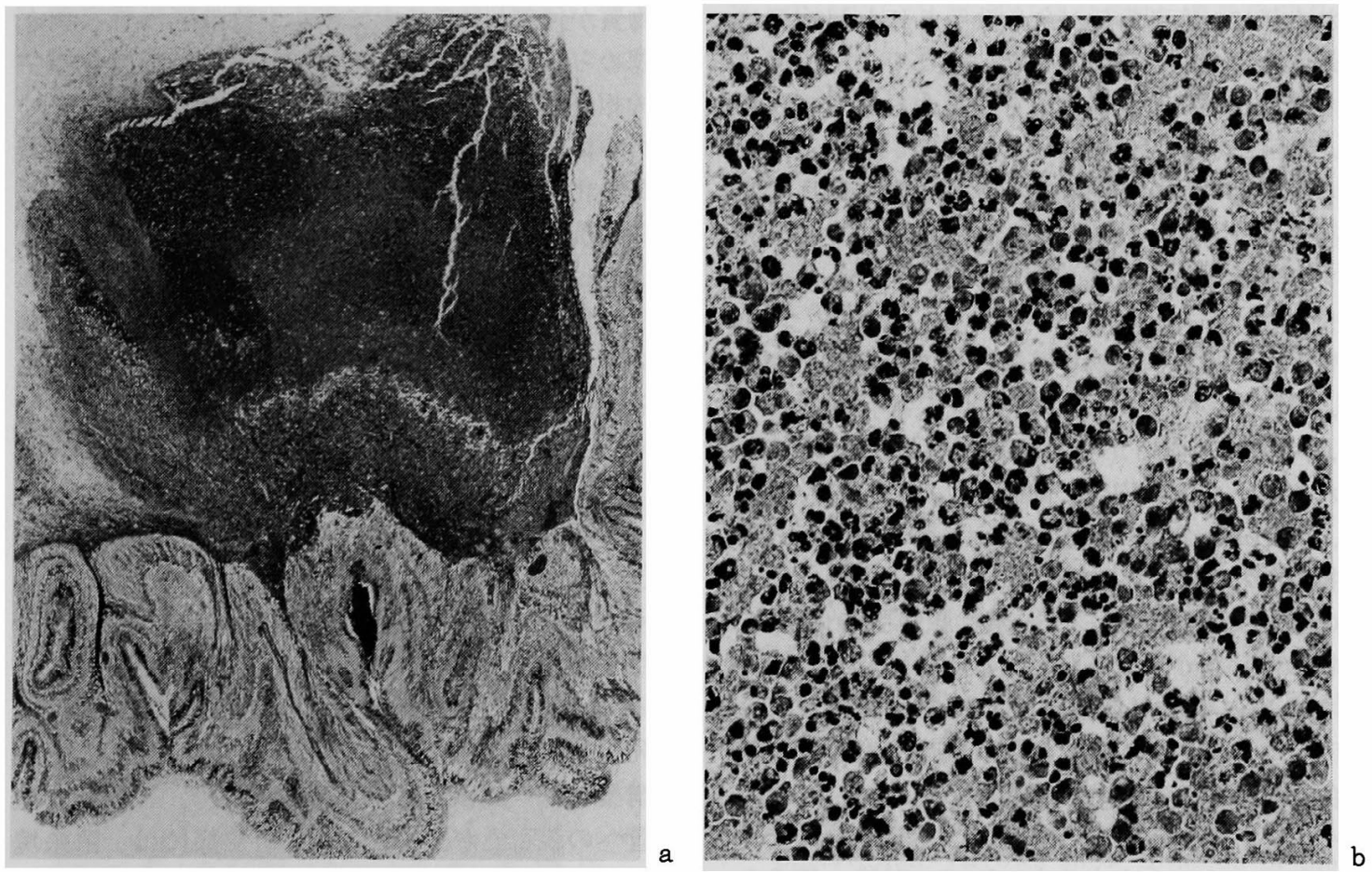

Fig. 7. Histology of the candidial endophthalmitis in an untreated case. (PAS reaction, $a: \times 4$, b : $\times 320)$ 

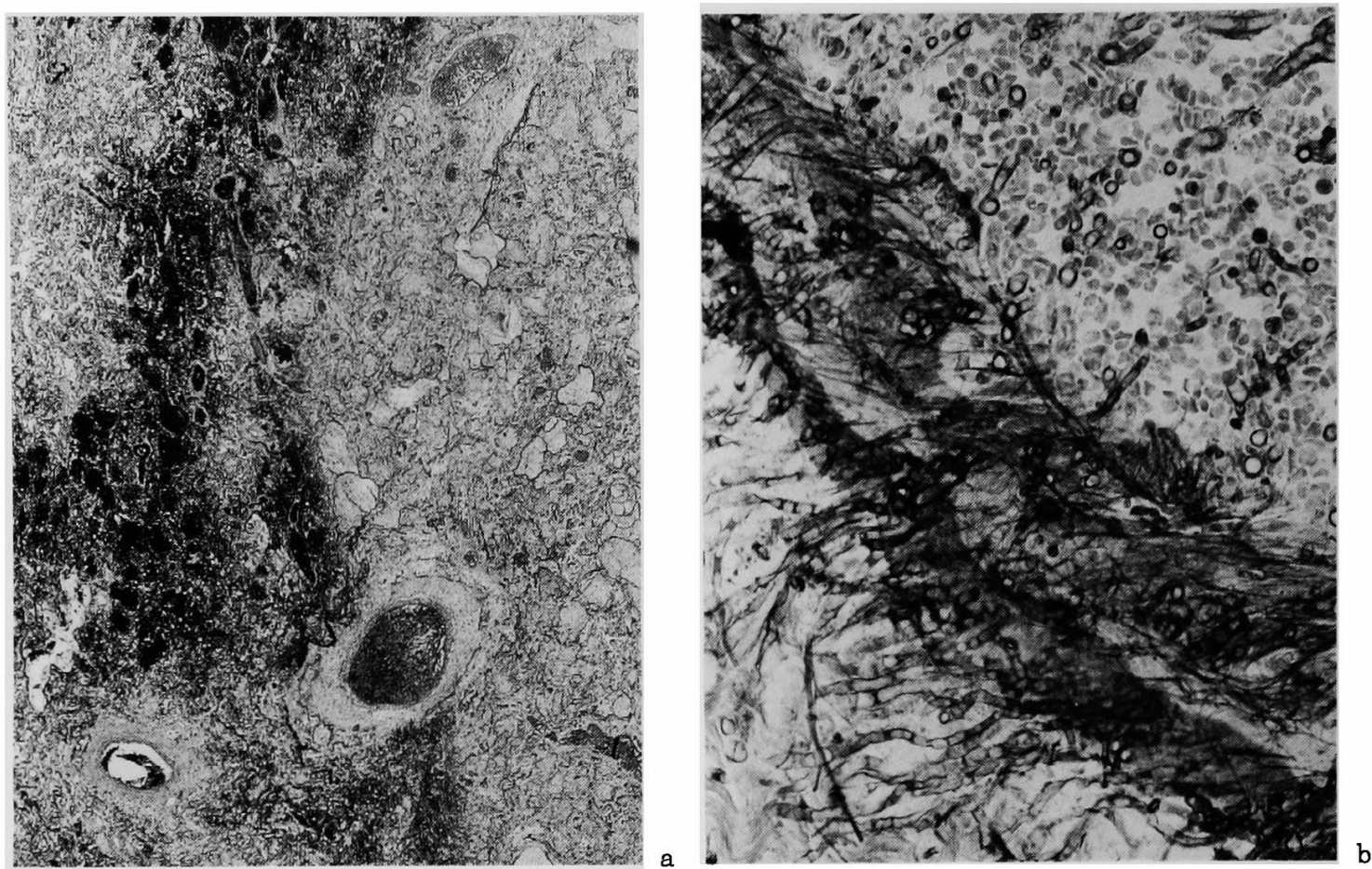

Fig. 8. Histology of pulmonary aspergillosis. (PAS reaction, a : $\times 10, b: \times 400$ )

された後に，抗真菌剤が全身投与された剖検例に 遭遇する機会が目立ってきた。ここでは，治療に より病変がどのように修飾されるかを考えてみた い. 材料として, 組織学的に明瞭な 3 層構造を有 する眼底部に病変を形成するために形態的比較が 容易であり，近年，増加傾向が指摘されている力 ンジダ性眼内炎を取り上げた.

まず初めに，治療例を示したい．本例は，コン トロール不良の糖尿病を基礎として発症したもの で, 視力低下を訴えた後に, 眼底に綿花状白斑を み，同時に末梢血から Candida albicans が培養 されカンジダ性眼内炎と診断された．この時点か ら, Fluconazole 及び Miconazole が, 各 1 カ月ず つ投与され，他の感染症で死亡した. 組織学的に この眼球では, 剥離した網膜と脈絡膜の間隙に, 楔状の肉芽腫が形成され，ここに組織球とリンパ 球ならびに少数の形質細胞の浸潤が認められる (Fig. 6). 剖検時の培養で菌は検出されず, 組織 学的にも菌要素は認められなかった.

一方，対照とした未治療例は，長期間のステロ イド投与の病歴を有するもの5)で, 剥離・褶曲し た網膜に, 多数の好中球や核破砕物を混じた壊死
物質が付着し，この中に極く少数の醉母様真菌が 認められた (Fig. 7). 両者間の最も大きな組織学 的相異点は, 治療例では肉芽腫性炎を形成してい たのに対し，未治療例では壊死と好中球浸潤の著 しい化膿性炎が認められた点である．すなわち， この抗真菌郕による治療例の持つ重要な意味は, Compromized hostにみられる代表的な所見とし ての化膿性炎が, 菌増殖の抑制によって治癒機転 の一つである肉芽腫性炎を経過し，廐痕治癒に至 る過程を示唆している点である.

\section{2. アスペルギルス症}

アスペルギルス症は，深在性真菌症の中で第 2 位の頻度をもつ代表的な真菌症の一つである. 多 くの場合, 空中に飛散したAspergillus spp. の分 生子を吸入することで, 肺に感染巣が形成され $ろ^{6)}$. 本症の病変の特徴は, 菌の増殖部周囲の壊 死と著明な出血であり, 組織内の菌は既存の組織 構筑とは無関係な菌系性発育を示す7)。特に，血 管への親和性が強いとされ, 病変部には, 菌系塊 から成る塞栓がしばしば認められる（Fig. 8).

そこで，今回我々は本症でしばしば認められる 


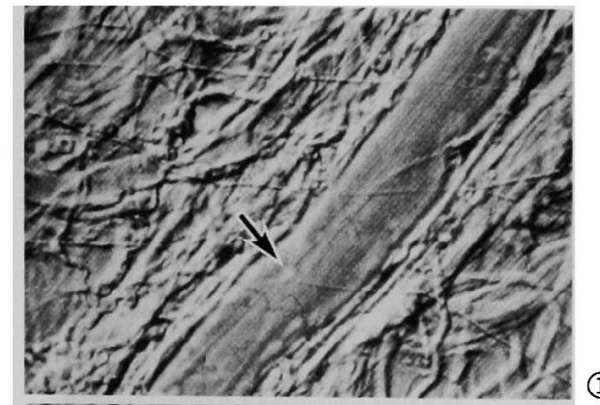

(1)
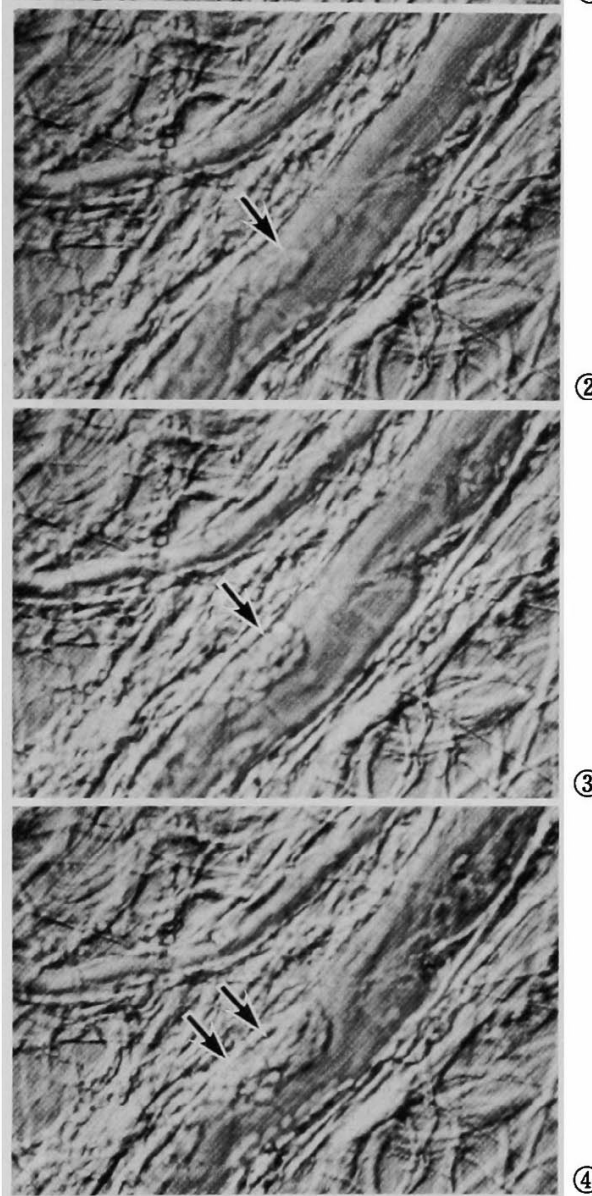

(4)

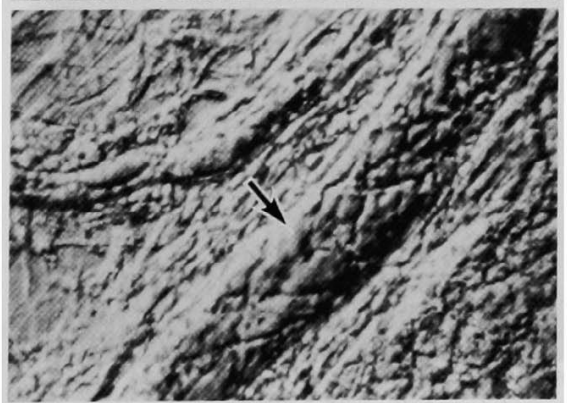

菌の血管内への侵入をラットの腸間膜モデルを用 いて実験的に再現しこれを微速度撮影によって 動態的に観察した結果を示したい．Aspergillus fumigatusの分生子浮遊液をラット腸間膜上に滴 下し, 微分干涉顕微鏡を介して微速度撮影を行なっ た.また，ラットは cyclophosphamide (CY) 投 与群および非投与群の両者について検討した。 $\mathrm{CY}$ 投与群では, 分生子の滴下後, 5 時間から 6 時 間目に菌糸の伸長が開始され，垂直に近い角度で 血管壁に到達した菌系は血管壁を貫通し，血管内 腔に菌系を伸長して行く.この貫通部の血管壁や 菌系の周囲には血小板や赤血球がしだいに付着し てゆき, 菌液滴下後 24 時間目以後には血栓や出 血巣が形成された（Fig．9）。血管内での菌の形態 は, 生体内で比較的特異的に真菌を検出しうる蛍 光色素であるファンギフローラY (バイオメイト 社製）を静脈注射することで明瞭に観察すること が可能であった（Fig. 10)。この観察時間内で腸 間膜上の分生子や菌系に対する白血球の遊走は, ほとんど認められなかった。これに対し，CY 非 投与群では菌系の伸長が開始される前，すなわち 分生子浮遊液滴下後約 6 時間以内にすべての腸間 膜上の分生子が白血球に貪食され，菌糸の伸長や 血管への侵入は全く認められなかった.

この結果は, CY 投与によって惹起される汎白 血球減少状態では，Aspergillus が生体内に侵入 した場合には, 組織に定着後約 6 時間から菌系の 伸長が開始され，感染後 1 日目から組織破壊を伴っ た菌系の伸長と微小な出血巣が形成される事実を 示唆するものであろう. また, 健常者 (Immunocompetent host）では，仮に分生子が組織内に侵 入しても菌糸の伸長を待たずして遊走してきた白 血球によって処理されるものと推定された.

\section{3. クリプトコックス症}

本症は, Compromized hostのみならず特定の 免疫能の低下のみられない患者にも発症すること で重要な深在性真菌症といえよう8). 感染経路と しては経気道感染が一般的であり，多くの場合肺 に感染巣を形成する ${ }^{9)}$ 。この後に，血行性に菌が

Fig. 9. Still photographs of slow speed observation. Arrows show invasion of the elongated hypha into the mesenteric vein of the rat 

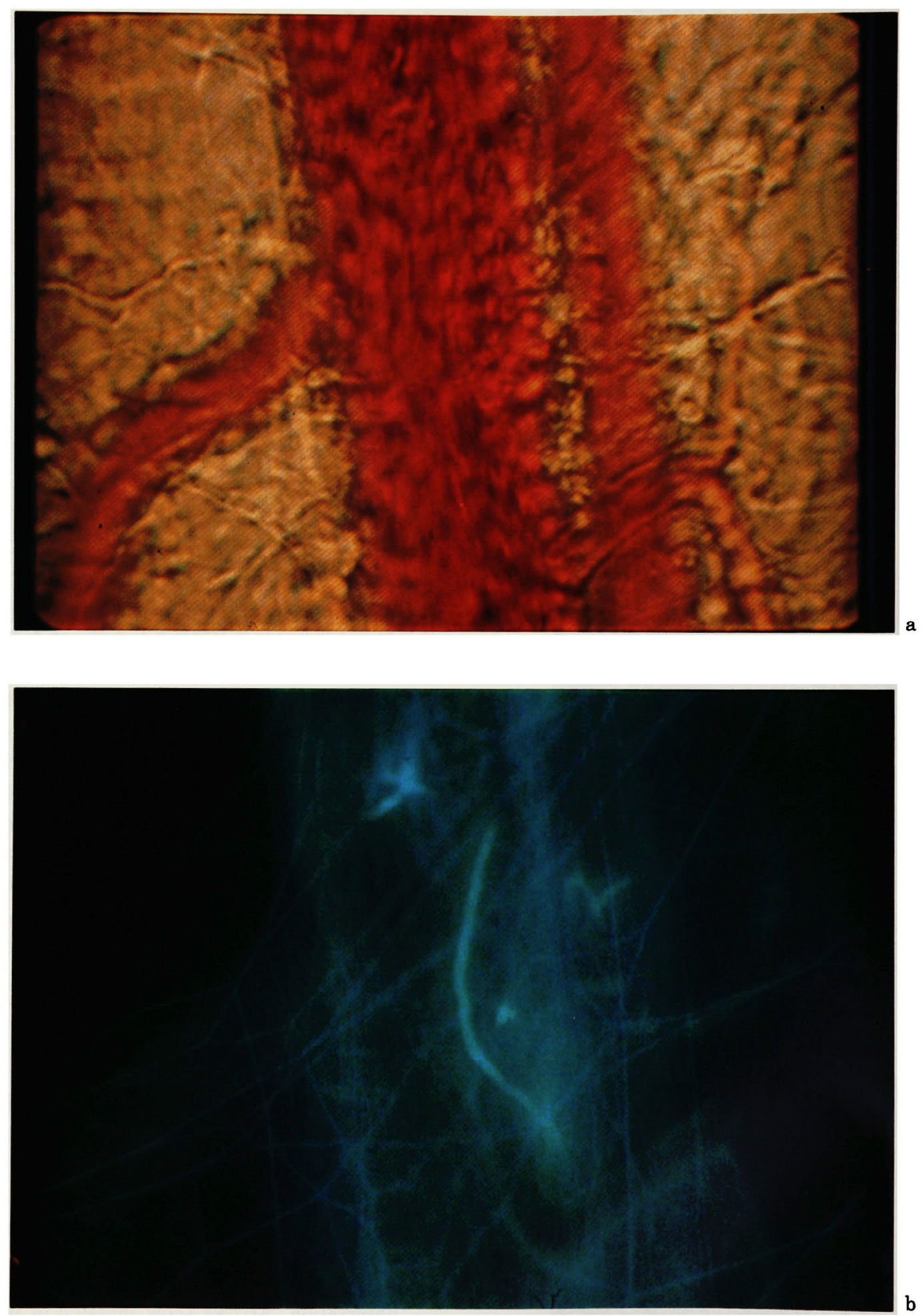

Fig. 10. Still photographs of the mesenteric vein of a rat treated with intravenous injection of a fluorescent substance. ( $a$ : control, $b$ : observed by fluorescence microscope) 


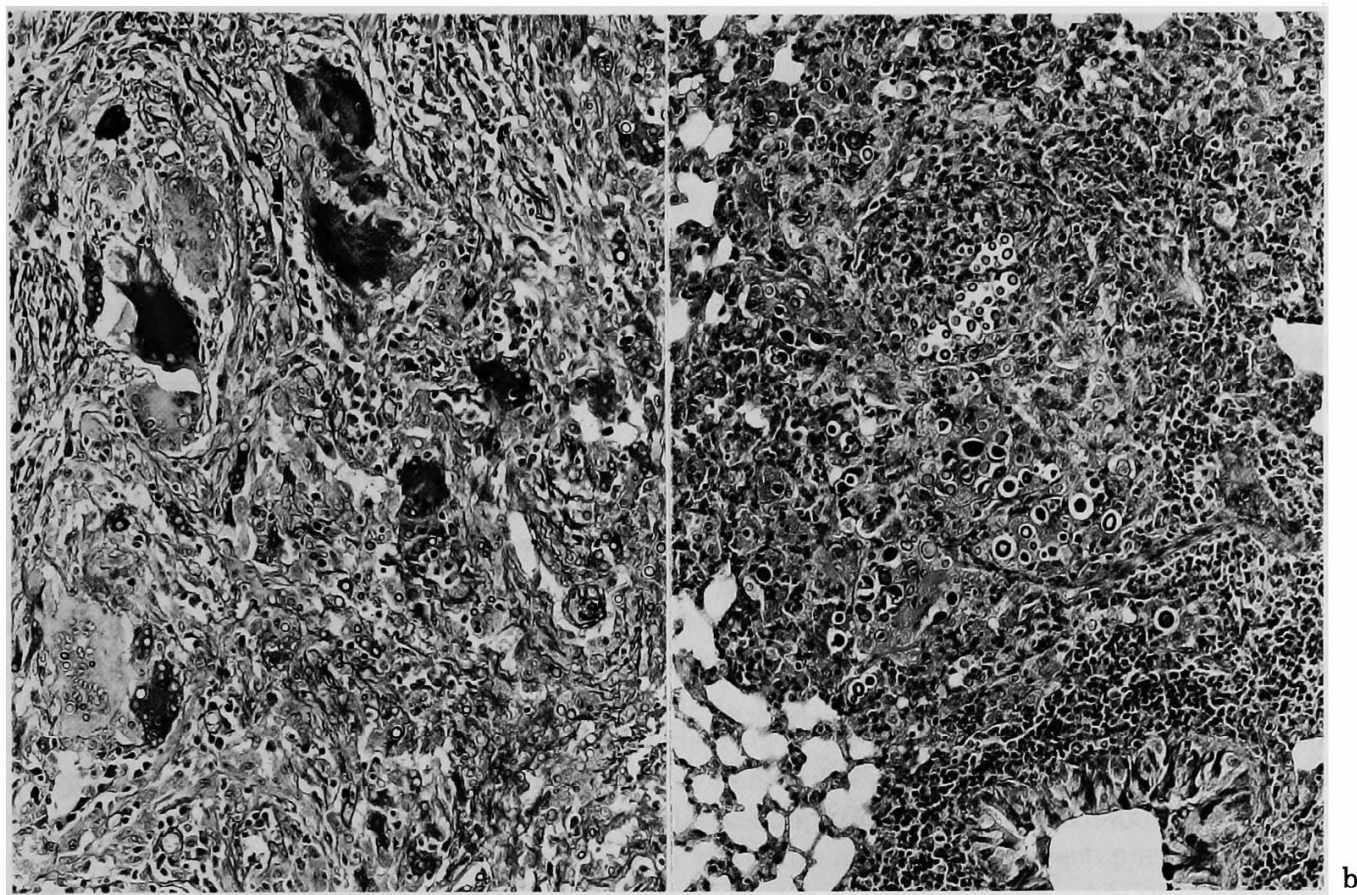

Fig. 11. Granulomas of the pulmonary cryptococcosis. Photograph "a" shows a granuloma developed in an immunocompetent host and " $b$ " shows a lesion developed in an untreated mouse. (PAS reaction, $a$ and $b: \times 200$ )

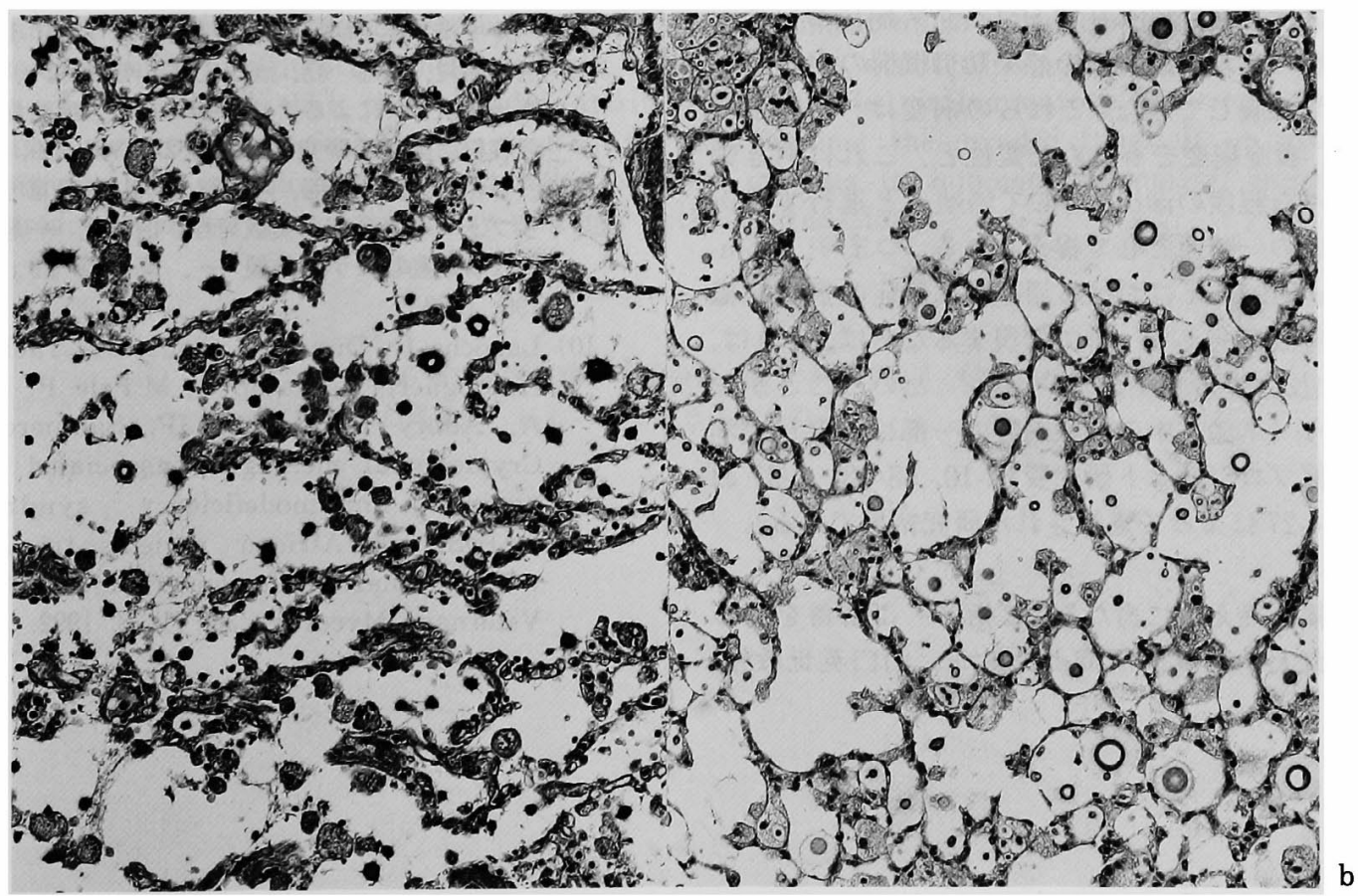

Fig. 12. Cystic lesions of pulmonary cryptococcosis. Photograph "a" shows a cystic lesion developed in a lung cancer patient and " $b$ " shows a lesion developed in a mouse treated with cyclosporin. (PAS reaction, $a$ and $b: \times 200$ ) 
散布され髄膜炎を惹起するといわれている。ヒト 原発性肺クリプトコックス症では, 多くの場合肺 に菌要素を被包した肉芽腫が形成される。一方, Compromized hostに発症した場合には, 肺組織 内での著しい菌の増殖に対し組織の反応はほとん どない, いわゆる震胞病変が成立することが一般 的である（Fig. 11，12）. 我々は，これまでに経 鼻接種により成立するマウスの肺クリプトコック ス症に関する検討を行ない, Cryptococcusの感染 防御には Class- II 分子に拘束された細胞間相互作 用が特に重要であることを示してきた。中でも， $\mathrm{CD} 4$ +細胞の障害時には, 一度菌に対して遊走し た肺胞大食細胞からなる幼若な肉芽腫が菌の増殖 に伴って分散・離開し，全身性クリプトコックス 症を惹起することなどを明らかにした ${ }^{3,9)}$.これら の実験結果は, クリプトコックス症が他の深在性 真菌症と比較して, 特に AIDS で発症頻度が増加 するという報告を支持するものと考えて矛盾しな いものである10).

これまでに, Compromized hostに発症する代 表的な深在性真菌症であるカンジダ症, アスペル ギルス症ならびにクリプトコックス症について， 各疾患の病理学的特徵を感染防御機構の相異を中 心として論じてきた.これらの病変は, 組織学的 には，襄胞病変をも含めた変性と，これに引き続 く様々な程度の淩出, そして增殖へと進行する炎 症反応の一断面として捉えられる。つまり, Compromized hostにおける深在性真菌症の病理組織 学的特徴をあえて一言で表現するならば, それは, “洷出反応が著しく乏しい炎症”ということがで きよう（本論文中の記載内容の一部は, 東邦大学 医学部プロジェクト研究費 62-10, 63-33，1-27 お よび4-27によって遂行された研究結果である).

本稿を終えるに当たり，ご指導・ご助言を賜っ た帝京大学医真菌研究センター, 山口英世教授,
内田勝久助教授，ならびに東邦大学医学部第一内 科，金子晴生講師に深甚の意を表します。さらに， 微速度撮影に関して，多大なご協力をいただいた 株式会社アイカム, 富田 勉・小澤英治両氏に心 より感謝いたします。

\section{文献}

1）奥平雅彦: 日本病理学会における真菌症に関する 研究のあゆみ (1911-1973). 真菌誌 $15: 61$-69, 1974.

2) 奥平雅彦: Opportunistic Fungus Infection の病理. 日病会誌 74:61-91, 1985.

3）渋谷和俊, 若山 恵, 直江史郎, 内田勝久, 山口 英世 : 病原酵母を用いた実験的肺肉芽腫に関する 免疫組織学的研究. 炎症 $10: 361-366,1990$.

4）望月真弓 : 内臟真菌症の発症病理に関する研究 一白血病患者に扔ける易感染性判別式一. 真菌 誌 $33: 51-63,1992$.

5）渋谷和俊, 安藤充利, 跡部俊彦, 直江史郎, 大野 研一, 戸張幾生, 石田哲朗 : 内因性カンジダ性眼 内炎をみた 1 剖検例. 真菌誌 $25: 247-252,1984$.

6）内田勝久, 山口英世 : アスペルギルスの菌学的検 査法. Aspergillosis, (池本秀雄編), p.13-20, 協和企画通信, 1989.

7）渋谷和俊, 若山 恵, 高橋 啓, 直江史郎 : アス ペルギルス症. 病理と臨床 $9: 1279-1284,1991$.

8）啮谷和俊, 浅地 聡, 直江史郎, 内田勝久, 山口 英世 : マウスによるクリプトコックス症発症機序 の解析に関する研究. 真菌誌 $28: 349-359,1987$.

9）啮谷和佁, 直江史郎, 内田勝久, 山口英世 : 肺ク リプトコックス症の実験病理学的研究 一経鼻接 種による動物モデル作製 一。真菌誌 $29: 182$ 190, 1988.

10) Laroche R, Dupont B, Touze JE, Taelman H, Bogaerts J, Kadio A, M'Pele P, Latif A, Aubry P, Durbec JP, Sauniere F: Cryptococcal meningitis associated with aquired immunodeficiency syndrome (AIDS) in African patients ; treatment with fluconazole. Journal of Medical and Veternary Mycology 30 : 71-78, 1992. 


\title{
Pathology of Deep Mycoses on Immunocompromised Host
}

\author{
Kazutoshi Shibuya, Megumi Wakayama, Shiro Naoe \\ Department of Pathology, Toho University Ohashi Hospital
}

A large body of deep mycoses, candidiasis, aspergillosis, cryptococcosis and mucor mycosis, had been increasing as opportunistic infections in Japan. The increasing number of patients and importance of establishing correct diagnostic procedures have been pointed out by those in medical mycology research; however, the pathogenesis of these mycoses, an essential aspect of each disease, remains unsolved.

Histopathological characteristics of deep mycosis onset in immunocompromised hosts were determined from autopsy cases of renal candidiasis in leukemic patients, endogenous candidial endophthalmitis, pulmonary aspergillosis and human and experimental pulmonary cryptococcosis, and the histological examinations are reported in this paper. A close relation between white blood cell (WBC) counts and the characteristics was found in renal lesions in candidial infection, e.g. the lesions developed in leukopenic patients displayed by prominent hyphal growth of Candida spp. appearing to disperse radially from the center, and less apparent inflammatory cell infiltrates. In contrast, necrosis and polymorphonuclear cell infiltrates, encompassing invaded and proliferated yeasts, were observed in the lesions which developed in patients retaining a normal WBC count. In a comparison of cases of candidial endophthalmitis treated and untreated with antifungal agents, the chemotherapy appeared to have the ability to convert purulent inflammation into granulomatous inflammation as a characteristic of this disease. An observation using time-lapsed filming of the growth of Aspergillus on rat mesenterium showed the importance of leukocytes in peripheral blood in defending against fungal invasion. Furthermore, comparative study of pulmonary cryptococoosis in immunocompromised and immunocompetent hosts using human and experimental lesions revealed that the development of so-called cystic lesion, characterized by lack of infiltrating inflammatory cells, may be a result of depression of CD $4+$ cells.

It was considered that these results attributed the varied inflammatory reactions to the manifestation of the defense mechanism of the host against the invaded fungi. If an attempt to provide the pathological characteristic of deep mycosis in immunocompromised hosts are required, it will be an inflammatory reaction without exudation. 